Bolm. Zool., Univ. S. Paulo $9: 225-230,1985$

\title{
PARATHYROID GLAND OF RANA CYANOPHLYCTIS DURING DEVELOPMENT
}

\author{
LALIT KRISHNA
}

Department of Zoology, University of Gorakhpur, Gorakhpur - 273001 , India. (recebido em 30.IV 1985)

RESUMO - No estágio inicial, objeto deste estudo, a glândula paratiróide de Rana oyanophiyctis è uma pequena bola sólida de células epiteliais. Durante a prometamorfose a glândula aumenta de tamanho por proliferação celular. No clímax da me tamorfose a glândula parece ser ativa, como é evidenciado pé la presença de núcleos hipercromáticos e núcleos picnóticos. ABSTRACT - The parathyroid gland of Rana cyanophlyctis is a small solid ball of epithelial cells at the earliest stage in the present study. During prometamorphosis the gland in creases in size due to cellular proliferation. At the time of metamorphic climax gland appears to be active as evident by the presence of hyperchromatic nuclei and pycnotic nu clei.

\section{INTRODUCTION}

On the phyletic scale the parathyroid gland first appears in amphibians. There are several reports on the morphology of parathyroid glands in adult anurans (Romeis, 1926 ; Waggener, 1929; Shapiro, 1933; Cortelyou et al., 1960 ; Boschwitz, 1961, 1965; Von Brehm, 1963, 1964; Cortelyon \& Mcwhinnie, 1967; Sasayama \& Oguro, 1974) but only few des criptions about the morphological changes of parathyroid glands of anurans during development are available (Maurer, 1888; Studitsky, 1945; Boschwitz, 1961) An attempt has, the refore, been made to study the changes undergone by the para thyroid gland of Rana cyanophlyctis during development.

\section{MATERIALS AND METHODS}

Tadpoles of Rana oyanophlyctis' were collected locally. Different stages (Table 1 ) of development and metamorphosis were determined according to Agarwal \& Niazi (1977 - in Rana tigrinal and were fixed in aqueous Bouin, dehydrated in graded alcohol and embedded in paraffin wax. Serial sections we re cut at 4-6 $\mu \mathrm{m}$ and stained with Haematoxylin/eosin.

The volume of the parathyroid gland at different stages was calculated by the following formula - volume $=4 / 3$ 
$a b^{2}$ (where a is major semiaxis and $b$ is minor semiaxis) be cause the gland is a prolate spheroid. Since there are four parathyroid glands (one pair on each side) the volume of the paired parathyroid of one side was determined and then doubled.

\section{OBSERVATIONS}

The parathyroid glands at stage 32 are two small so lid balls on each side at the level of 3 rd and 4 th branchial pouch. The glands are composed of epithelial cells with chro matin-rich nuclei and are highly vascularized at the periphe ry (Fig. 1)

During prometamorphosis (stages 33-45) the glands show progressive increase in size (Table 1) due to cellular proli feration (Fig. 2) At the end of prometamorphosis (stage 48) the glands become oval in shape having densely packed epithe lial cells (Fig. 3 ).

At the time of metamorphic climax (stages 50-55) hyper chromatic nuclei are observed. Few cells with pycnotic nu clei have been encountered at the periphery of the glands (Fig. 4)

In froglets a pair of parathyroid glands (ovoid structures) are situated on each side of glottis anterior to the ultimobranchial bodies. The glands are composed of densely packed epithelial cells and are enveloped by connective tis sue and blood capillaries.

\section{DISCUSSION}

In Rana cyanophlyctis parathyroid glands are seen at the level of $3 \mathrm{rd}$ and $4 \mathrm{th}$ branchial pouches at stage 32 (oper culum fused with skin). This derives support from the ear lier observations of Maurer (1888) and Boschwitz (1961) who have stated that the parathyroid glands in anurans originate from the ventral part of $3 \mathrm{rd}$ and $4 \mathrm{th}$ branchial pouches at the time of inner gill formation.

The parathyroid glands at stage 32 (Table 1)are small solid balls (two on either side) of epithelial cells with conspicuous nuclei. Similar observations about the structure of parathyroid glands have been made in Bufo viridis (Boschwitz, 1961) and Bufo andersonii (Swarup \& Pandey, unpublished).

During prometamorphic stage of anuran development there is an active accumulation of calcium in.the paravertebral lime-sacs for the further utilization in the ossification of bone during metamorphic climax (Guardabassi, 1960; Pilking ton \& Simkiss, 1966; Simkiss, 1967) So during these stages an active turnover of calcium occurs (Simkiss, 1967; Baldwin \& Bentley, 1980). The occurrence of hyperchromatic nuclei and also the existence of certain pycnotic nuclei (of the exhausted cells) in the parathyroid glands of Rana cyano phlyctis indicate the active state of the glands which justi 
fies an active turnover of calcium at this stage thus suppor ting the above statements. Further, Studitsky (1945) has also reported an active state of parathyroid gland at the time of skeletal ossification during metamorphosis.

\section{SUMMARY}

The parathyroid glands of Rana cyanophlyctis at different stages of development have been studied. The earliest stage of development (32) undertaken in the present study exhibits glands as two small solid balls of epithelial cells on either side at the level of 3 rd and 4 th branchial pou ches. During prometamorphosis (stages 33-45) glands show pro gressive increase in size due to cellular proliferation. At the time of metamorphic climax (stages 50-55) glands appear to be active as evident by the presence of hyperchromatic nu clei and few pycnotic nuclei at the periphery of the gland.

\section{REFERENCES}

AGARWAL, S.K. \& I.A. NIAZI 1977 Normal table of developmental stages of the Indian bullfrog, Rana tigrina Daud.(Ranidae, Anura, Amphibia). Proc. Nati.Acad.Sci. India, $47 B: 79$ -92 .

BALDWIN, G.F. \& P.J BANTLEY 1980. Calcium metabolism in bullfrog tadpoles (Rana catesbeiana). J.Exp. Biol., 88:357 -365 .

BOSCHWITZ, D. 1961. The parathyroid glands of Bufo viridis Laurenti. Herpetologica, 17:192-199.

BOSCHWITZ, D. 1965. Histological changes in the parathyroids of Bufo viridis Laurenti. Israel J.Zool., 14:11-23.

CORTELYOU, J.R. \& MC WHINNIE 1967 Parathyroid glands in amphibians. I. Parathyroid structure and function in the am phibian with emphasis on regulation of mineral ions in boㅡ dy fluids. $A m$. Z00Z., 1:843-855.

CORTELYOU, J.R., A. HIBNER-OWERKO \& J. MULROY 1960. Blood and urine calcium changes in totally parathyroidectomized Rana pipiens. Endocrinology, 66:441-450.

GUARDABASSI, A. 1960. The utilization of the calcareous depo sits of the endolymphatic sacs of Bufo bufo bufo in the mineralization of the skeleton. Investigations by means of $\mathrm{Ca}^{45}$. Z. Zel Zforsch., 51:278-282.

MAURER, F: 1888. Schilddruse, Thymus and Kiemenreste der Amphibien. Morph.Jahrb., 13:296-382.

PILKINGTON, J.P. \& K. SIMKISS 1966. The mobilization of the calcium carbonate deposits in the endolymphatic sacs of metamorphosing frogs. J.Exp.Biol., 45:329-341.

ROMEIS, B. 1926. Morphologische und experimentelle Studien uber die epithelkörper der Amphibien I. Die Morphologie der Epithelkörper der Anuran. Z.Anat.Enturcklungegesch. , 80:547-578.

SASAYAMA, Y. \& C. OGURO 1974. Notes on the topography and morphology of the parathyroid glands in some Japanese anu 
rans. Ann. Zool. Japon., 47:232-238.

SHAPIRO, B.G. 1933. The topography and histology of the para thyroid glandules in Xenopus lasvis. J.Anat., 68:39-44.

SIMKISS, K. 1967. "Calcium in Reproductive Physiology" Chapman and Hall, London.

STUDITSKY, A.N. 1945. Function of parathyroid glands in am phibia. C.R.Acad.Sci., 47:444-447.

SWARUP, K. \& A.K. PANDEY (unpublished). Cytological changes in the parathyroid glands of Bufo andersonii (L) during development.

VON BREHM, H. 1963. Morphologische Untersuchengen an Epithel kbrperchen (Glandulae parathyroideae) von Anuren, Teil I. Z. Zelzforsch., 61:376-400.

VON BREHM, H. 1964. Experimentelle Studie zur Fraze der jahreszyklischen Verdderungen, morphologische Untersuchungen an epithelkorperchen (Glandulae parathyroideae) von Anu ren. Teil II. Z. Zellforsch., 61:725-741.

WAGGENER, R.A. 1929. A histological study of the parathyroids of anura. J.Morph., 48:1-43. 
Table 1 - General description, size of the tadpole and volume of parathyroid at different developmental stages of Rana cyanophlyctis

\begin{tabular}{|c|c|c|c|}
\hline Stage* & Description & $\begin{array}{l}\text { Size of } \\
\text { the tad } \\
\text { pole } \\
(\mathrm{mm})\end{array}$ & $\begin{array}{l}\text { Volume of } \\
\text { parathyroid } \\
\text { gland }\left(\mathrm{mm}^{3}\right)\end{array}$ \\
\hline 32 & Operculum fused with skin & 12 & 0.0015 \\
\hline 33 & Hind limb bud & 18 & 0.0042 \\
\hline 41 & Hind limb digits begin & 37 & 0.0069 \\
\hline 43 & $\begin{array}{l}\text { The toss are longer and } \\
\text { webs are prominent }\end{array}$ & 41 & 0.0368 \\
\hline 45 & $\begin{array}{l}\text { The angle between thigh and } \\
\text { shank approximately at } \\
\text { right angle }\end{array}$ & 46 & 0.0404 \\
\hline 48 & $\begin{array}{l}\text { The forelimbs are visible } \\
\text { through transparent skin in } \\
\text { ventral view }\end{array}$ & 63 & 0.0573 \\
\hline 50 & Both forelimbs have emerged & 55 & 0.0771 \\
\hline 53 & $\begin{array}{l}\text { Small tail, about } 3 / 4 \text { of } \\
\text { tail is resorbed, No trace } \\
\text { of fin }\end{array}$ & $28-34$ & 0.1825 \\
\hline 55 & $\begin{array}{l}\text { Froglet, Tail completely } \\
\text { resorbed }\end{array}$ & 24 & 0.1880 \\
\hline
\end{tabular}

*Developmental stages were determined according to Agarwal \& Niazi (1977) 


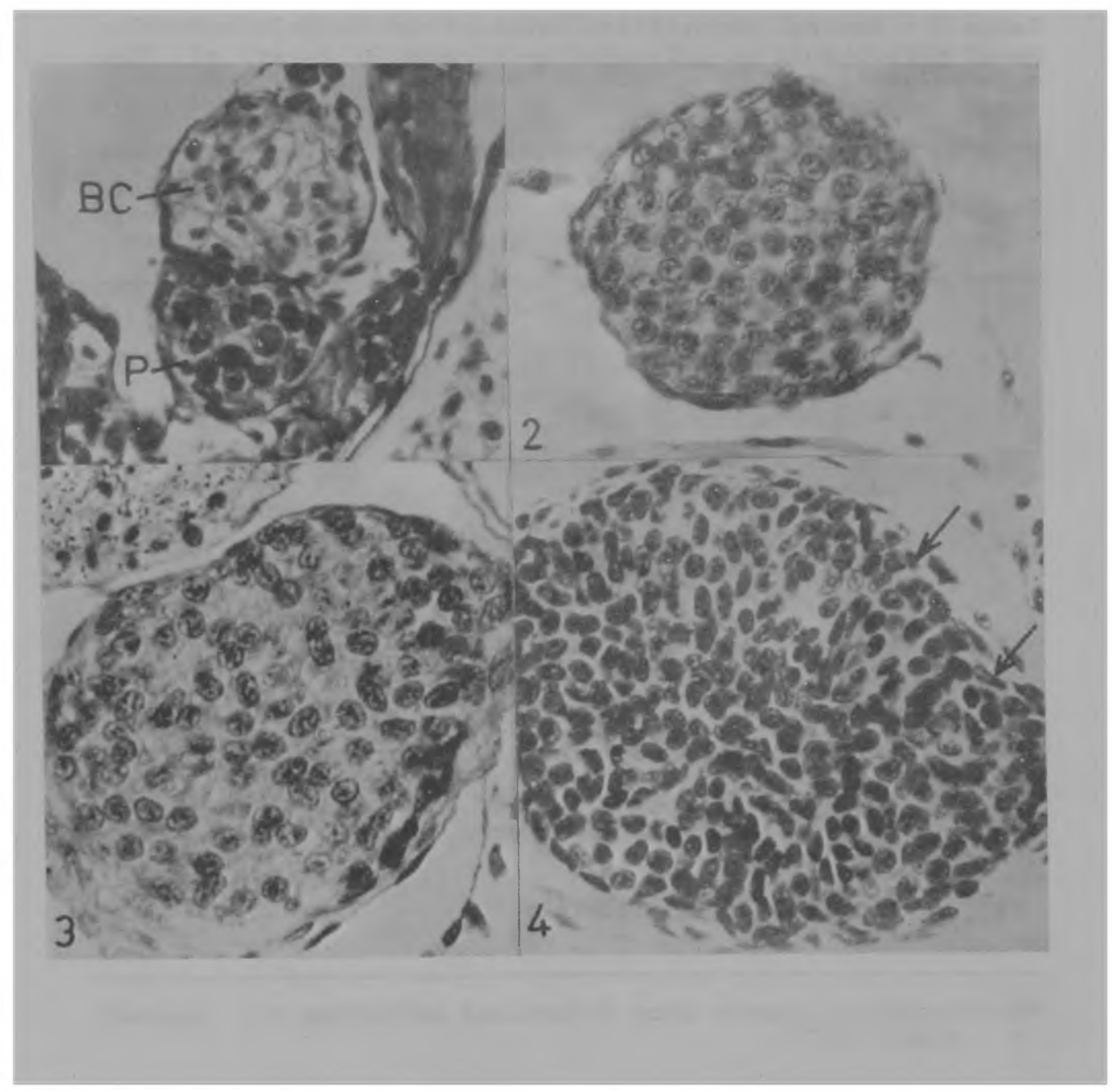

Figure 1 - Parathyroid gland (P) of $R$. cyanophlyctis at stage 32 . Note chromatin-rich nuclei and blood capillary (BC) at the periphery. Haematoxylin-eosin. X 500 .

Figure 2 - Parathyroid gland of $R$. cyanophlyctis at stage 41 showing increased size of gland due to cellular prolifera tion. Haematoxylin-eosin. X 500 .

Figure 3 - Parathyroid gland of $R$. cyanophlyctis at stage 48 showing further increase in size. Haematoxylin-eosin. X 500 . Figure 4 - Parathyroid gland of $R$. cyanophlyctis at stage 55 showing cells having hyperchromatic nuclei and few cells with pycnotic nuclei (arrows) Haematoxylin-eosin. X 500 . 